\title{
Aspek Praktis Nutrisi Parenteral pada Anak
}

\author{
Aryono Hendarto dan Sri S Nasar
}

Nutrisi parenteral (NP) merupakan salah satu alternatif dukungan nutrisi yang telah terbukti dapat menunjang tumbuh kembang anak selama sakit. NP diindikasikan untuk anak sakit yang tidak boleh atau tidak dapat mengkonsumsi makanan secara oral/enteral. Mengingat komplikasinya maka pemberian NP harus benar-benar memperhitungkan risk and benefit. Langlah-langkah pada tatalaksana NP meliputi: penentuan status nutrisi (klinik, antropometrik \& laboratorik), perhitungan kebutuhan nutrisi (energi, cairan dan nutrien), pemilihan dan perhitungan cairan yang akan digunakan serta cara pemberiannya (masing-masing atau all in one/three in one), penentuan akses NP (sentral atau perifer), pelaksaan pemberian dan pemantauan komplikasi.

Kata kunci: indikasi, kebutuhan nutrisi, akses NP, komplikasi.

$\mathcal{K}$ eberhasilan pemberian nutrisi parenteral modern pertama kali dilakukan oleh Wilnmore dan Dudrick tahun 1968 pada bayi yang dilakukan reseksi usus, tampak tumbuh dengan baik hanya dengan pemberian nutrisi parenteral saja. ${ }^{1}$ Nutrisi parenteral ini sudah mulai diperkenalkan sejak abad ke 17 ketika Giovanni Colle melakukan transfusi darah untuk pertama kali pada tahun $1628 .^{2}$ Selanjutnya Sir Christopher Wren memberikan nutrien dan obat ke dalam vena seekor anjing. ${ }^{3}$ Tahun 1945 Helfrik dan Abelson memberikan infus dekstrosa 5\%, kasein hidrolisat 10\% dan emulsi olive oil lesitin selama 5 hari pada bayi marasmus berusia 5 bulan. ${ }^{4}$ Sejalan dengan kemajuan ilmu pengetahuan secara umum dan khususnya teknologi kedokteran, maka nutrisi parenteral (NP) pun telah secara luas dan relatif aman digunakan pada berbagai keadaan klinis baik untuk jangka pendek ataupun untuk jangka waktu lama. Walaupun nutrisi enteral lebih aman dan lebih murah serta lebih sedikit

Subbagian Gizi \& Metabolik. Bagian Ilmu Kesehatan Anak FKUIRSCM. Jl.Salemba no. 6, Jakarta 10430. (Dr. Sri S Nasar, Sp.A(K))

Alamat korespondensi: Dr. Aryono Hendarto, Sp.A(K).

Subbagian Gizi \& Metabolik. Bagian Ilmu Kesehatan Anak FKUIRSCM. Jl.Salemba no. 6, Jakarta 10430.

Telepon: 021-391 5715. Fax.: 021-390 7743. komplikasinya, NP masih dan akan tetap mendapat tempat dalam tatalaksana pasien di klinik. NP adalah pemberian nutrisi yang mengandung karbohidrat, protein, lemak, vitamin dan mineral melalui vena yang utuh. Tujuannya adalah untuk memberikan nutrien yang dibutuhkan agar anak dapat tumbuh kembang seperti anak lain yang mendapat dukungan nutrisi enteral. ${ }^{5}$

Masalah yang sulit pada tatalaksana NP pada anak adalah menentukan kapan NP harus dimulai serta tidak mudah memenuhi kebutuhan nutrisi khususnya energi yang jauh lebih tinggi dibandingkan orang dewasa. Selain itu, teknis juga lebih sulit mengingat ukuran pembuluh darah yang lebih kecil, terutama pada NP perifer.

\section{Indikasi NP}

NP diberikan sebagai dukungan nutrisi bagi pasien yang tidak dapat mengkonsumsi atau menyerap sejumlah makanan secara adekuat melalui traktus gastrointestinal selama paling sedikit 5-7 hari. Yang termasuk dalam kelompok ini adalah pasien yang karena sesuatu sebab atau keadaan tidak dapat, tidak boleh atau tidak mau makan sehingga tidak mampu memenuhi kebutuhan bila hanya mendapat masukan peroral. ${ }^{5}$ Sedangkan kontraindikasi pemberian NP adalah pasien yang dapat mengkonsumsi nutrisi enteral sesuai atau melebihi kebutuhan atau pemberian nutrisi 


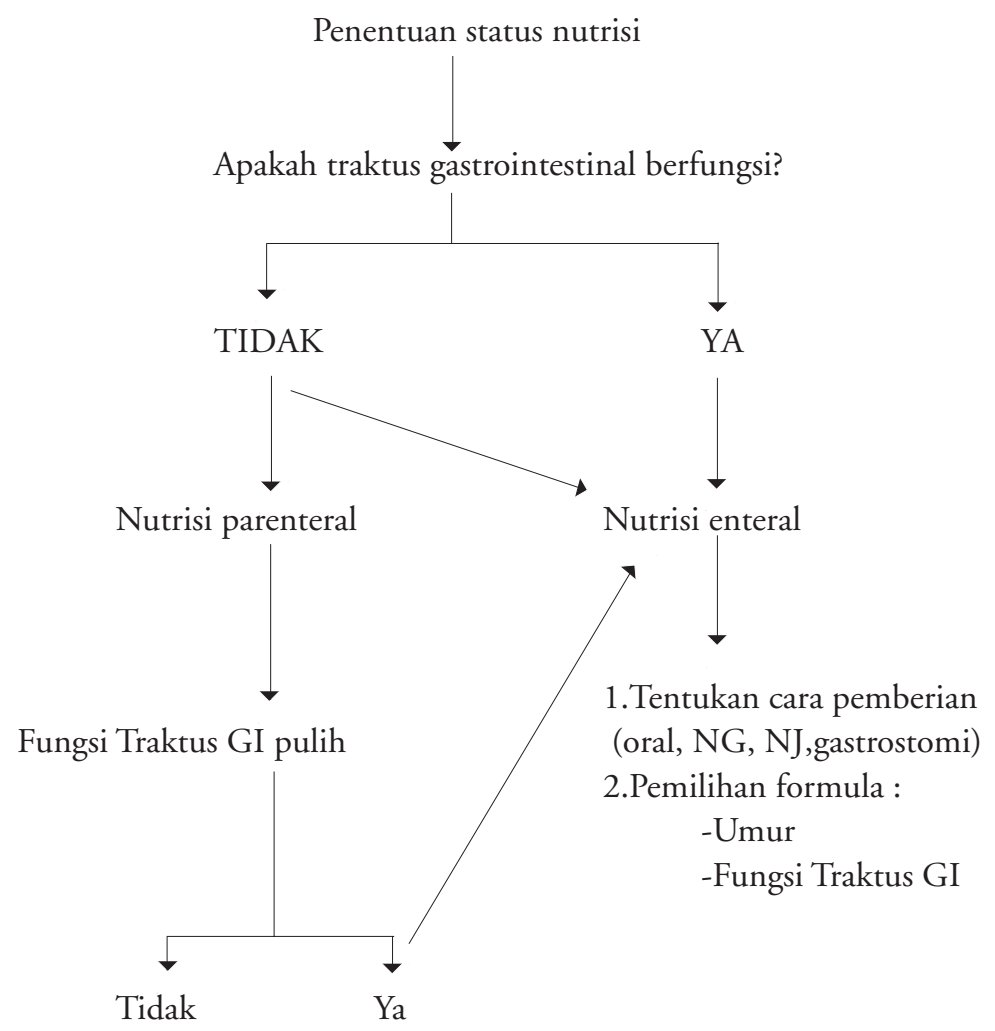

Gambar 1. Algoritma dukungan nutrisi pada pediatri ${ }^{6}$

parentral memberikan efek samping yang lebih berbahaya dibandingkan penyakit dasarnya. ${ }^{5}$ (Tabel 1)

\section{Langkah-langkah pada tatalaksana NP ${ }^{8}$}

- Penentuan status nutrisi (klinik, antropometrik \& laboratorik)

- Perhitungan kebutuhan nutrisi (energi, cairan dan nutrien)

- Pemilihan dan perhitungan cairan yang akan digunakan serta cara pemberiannya (masingmasing atau 'all in onelthree in one')

- Penentuan akses NP (sentral atau perifer)

- Pelaksanaan pemberian NP

- Pemantauan:

- keadaan klinik danlaboratorik

- komplikasi (mekanik, septik dan metabolik)

\section{Penentuan status nutrisi ${ }^{8,9}$}

Bila sudah diputuskan untuk pemberian NP, selanjutnya adalah menentukan status nutrisi pasien secara klinis, antropometrik dan laboratorik. Secara klinis dengan pemeriksaan fisik umumnya dapat dilihat proporsi tubuh, jaringan lemak subkutis, tonus dan trofi otot. Secara antropometri dapat digunakan BB/U, TB/U, BB/ TB, LILA dan TLK, sedang pada neonatus atau bayi dapat ditambahkan pemeriksaan lingkar kepala dan lingkar dada. Indikator laboratorik untuk menunjang status nutrisi antara lain nilai $\mathrm{Hb}$, hitung limfosit, albumin, transferin, pre-albumin, RBP dan komposisi tubuh (TBW, Bioelectrical impedance, Dual energy X-Ray absorptiometry), status nutrisi ikut menentukan kebutuhan nutrisi pasien tersebut apakah akan diberi NP-rumat atau NP-replesi.

Merrit dan Blackburn membuat pedoman untuk mengindentifikasi apakah anak memerlukan terapi NP-replesi atau NP-rumatan

Kelompok 1:

- $\quad$ serum albumin $<2.5 \mathrm{~g} / \mathrm{dl}$

- transferin $<100 \mathrm{ug} / \mathrm{dl}$

- hitung limfosit $<1000 / \mathrm{mm}^{3}$

- $\quad$ anergi ( tanpa steroid, di luar masa bayi )

- $\mathrm{BB} / \mathrm{TB}<-2 \mathrm{SD}$ atau $<80 \%$ standar

- masa otot lengan $<\mathrm{P}_{5}$

- $\mathrm{CHI}<60 \%$ standar

- status protein skelet atau viseral marginal

- stres berat 
Tabel 1. Kondisi/keadaan yang kemungkinan memerlukan $\mathrm{NP}^{6}$

I. Pasien tidak mampu mentoleransi nutrisi enteral karena disfungsi traktus GI.

- Pasca bedah neonatus: gastroschisiz, atresia esophageal, atresia intestinal multiple, ileus mekonium dengan peritonitis, malrotasi dan volvulus, $\mathrm{MH}+$ enterokolitis, hernia diafragmatika.

- Reseksi usus yang panjang

- Fistula gastrointestinal

- Penyakit GI berat: EKN, inflammatory bowel disease, pankreatitis

- Malabsorbsi berat

- Diare intraktabel pada bayi

- Pemberian kemoterapi dengan atau tanpa iradiasi

- Transplantasi tulang dan organ lain

- BBLSR dengan penyakit saluran napas atau penyakit lain yang berat

- Chilothorax dan chiloacites

II. Pasien dengan kebutuhan metabolisme meningkat yang kemungkinan tidak adekuat dengan pemberian NP.

- Lukar bakar hebat dan trauma

- Fibrosis kistik

- Sepsis berat

- Gagal ginjal

- Gagal jantung berat

Kelompok ini secara definitif memerlukan terapi NP-replesi Kelompok 2:

- $\quad$ serum albumin $>3 \mathrm{~g} / \mathrm{dl}$

- transferin $<150 \mathrm{ug} / \mathrm{dl}$

- hitung limfosit $<1500 / \mathrm{mm}^{3}$

- $\mathrm{BB} / \mathrm{TB}>-2 \mathrm{SD}$ atau $<80 \%$ standar

- masa otot lengan $<\mathrm{P}_{5}$

- $\mathrm{CHI}$ (creatinin hight index) $<80 \%$ standar

Kelompok ini perlu pemantauan ketat terhadap kemungkinan deplesi jaringan tubuh yang melanjut serta paling tidak harus mendapat NP-rumatan. Bila juga menderita sepsis, pasien harus diperlakukan seperti kelompok 1 ( NP-replesi)

Kelompok 3:

- $\quad$ tidak mendapat defisit nutrisi

- tidak menderita penyakit kronik

- diperkirakan tidak mendapat stres berat karena situasi RS
Tabel 2. Pasien yang menerima NP di RS Osaka University Medical School tahun 1971-1996 ${ }^{7}$

\begin{tabular}{lrr}
\hline Kondisi/keadaan & Jumlah & $\%$ \\
\hline Pre \& pasca operasi & 834 & 48.5 \\
Terapi sitostatika & 377 & 21.8 \\
Gejala-gejala GI & & \\
(ileus, diarrhea, bleeding) & 139 & 8.1 \\
Asupan oral tidak adekuat & & \\
(termasuk tumor cachexia) & 99 & 5.6 \\
Komplikasi pasca operasi & 77 & 4.4 \\
Gangguan respiratorik & 68 & 3.7 \\
Disfungsi intestinal & 65 & 3.6 \\
Gagal hati/ginjal (multiorgan) & 29 & 1.6 \\
Lain-lain & 47 & 2.7 \\
\hline Total & 1717 & 100
\end{tabular}

Kelompok ini cukup mendapat NP-rumatan. Bila pasien menderita infeksi yang menyebabkan deplesi / starvasi atau akan menjalani operasi besar ( mayor), ulangi penilaian di atas dalam 1-2 minggu.

\section{Penentuan kebutuhan nutrisi}

Kebutuhan nutrisi dipengaruhi oleh berbagai faktor antara lain status nutrisi, umur, keadaan klinis dan penyakit yang diderita. Secara sederhana, umumnya kebutuhan energi pada anak hampir sama dengan kebutuhan cairan dan kebutuhan energi nutrisi parenteral lebih sedikit daripada nutrisi enteral. Prinsipnya kebutuhan energi pada pasien pediatri harus seimbang antara asupan energi dengan energi yang digunakan ditambah dengan kebutuhan untuk tumbuh. Kebutuhan bayi lebih tinggi dibandingkan anak yang terutama digunakan untuk sintesis protein dan pertumbuhan.

Energi: bermacam cara digunakan untuk menentukan besarnya kebutuhan energi.antara lain, tabel rumus kebutuhan yang dianjurkan (RDA), rumus HarrisBenedict dan modifikasinya untuk neonatus/ bayi, dan mengukur BEE atau REE (kalorimetri indirek)

Rumus Harris-Benedict umumnya digunakan untuk menentukan BEE anak diatas 10 tahun, tetapi telah dikembangkan pula untuk bayi sbb:

- Lelaki: $\mathrm{kkal} / 24 \mathrm{jam}=66.47+(13.75 \times \mathrm{xB})+$ (5.00xTB $)+(6.76 \mathrm{x}$ umur $)$

- Perempuan: kkal/24 jam $=6.55 .10+(9.576 x B B)$ 
$+(1.85 \mathrm{xTB})-(4.86 \mathrm{xU})$

- Bayi: kkal/24 jam: $22.10+(31.05 \times B B)+$ (1.16xTB)

Tergantung pada stres yang diderita, maka kebutuhan energi akan meningkat $=\mathrm{BEE} \times \mathrm{x}$ faktor stres, yaitu menjadi $1.25 \mathrm{x}$ pada stres ringan, $1.5 \mathrm{x}$ pada stres sedang dan $2 \mathrm{x}$ untuk stres berat.

Agar lebih praktisnya Tabel di bawah ini dapat dijadikan acuan dalam menghitung kebutuhan energi untuk nutrisi parenteral. (Tabel 3)

Tabel 3.Kebutuhan energi untuk NP

\begin{tabular}{cc}
\hline Umur & Kebutuhan kalori $(\mathrm{kkal} / \mathrm{kg} / \mathrm{hari})$ \\
\hline $\mathrm{NKB}$ & $120-140$ \\
$<6$ bulan & $90-120$ \\
$6-12$ bulan & $80-100$ \\
$1-7$ tahun & $75-90$ \\
$7-12$ tahun & $60-75$ \\
$12-18$ tahun & $30-60$
\end{tabular}

Beberapa keadaan dapat menaikkan kebutuhan energi seperti terlihat pada Tabel 4 di bawah ini Cairan: Kebutuhan cairan dipengaruhi oleh berbagai faktor, yaitu umur, ukuran tubuh, suhu tubuh dan lingkungan serta keadaan hidrasi pasien. Jumlah cairan tubuh anak lebih banyak dari orang dewasa (75\%: 60\%). Tabel 4 memperlihatkan kebutuhan cairan normal pada anak menurut $\mathrm{BB}$ dan golongan umur.

Kerner menganjurkan jumlah kebutuhan cairan yang dianjurkan

Jumlah cairan tersebut dapat dinaikkan bertahap untuk menambah asupan energi yang dikehendaki selama tubuh dapat mentoleransi

- Bayi:dinaikkan sebanyak $10 \mathrm{ml} / \mathrm{kg} /$ hari, sampai maksimum $200 \mathrm{ml} / \mathrm{kg} /$ hari

Tabel 4. Kondisi yang dapat menaikkan kebutuhan energi

\begin{tabular}{ll}
\hline Kondisi & Kenaikan Kalori \\
\hline Demam & $\begin{array}{l}12 \% \text { untuk setiap kenaikan } \\
\text { suhu } 1^{\circ} \text { diatas } 37^{\circ}\end{array}$ \\
Gagal Jantung & $15-25 \%$ \\
Bedah mayor & $20-30 \%$ \\
Luka bakar & Sampai $100 \%$ \\
Sepsis (berat) & $40-50 \%$ \\
Gagal tumbuh(kronik) & $50-100 \%$ \\
MEP & Sampai 2 C BEE \\
\hline
\end{tabular}

- $\quad$ BB>10kg: dinaikkan sebanyak $10 \%$ dari volume awal perhari dengan maksimum $2000 \mathrm{ml} / \mathrm{m}^{2} /$ hari.

Kebutuhan cairan dapat dilihat pada Tabel 5 dan Tabel 6 Protein: Kebutuhan protein pada anak selain untuk

Tabel 5. Kebutuhan cairan berdasarkan BB dan umur

\begin{tabular}{lll}
\hline Golongan Umur & BB $(\mathrm{kg})$ & Kebutuhan \\
\hline Bayi prematur/BBLR & $<2$ & $150 \mathrm{ml} / \mathrm{kg}$ \\
Neonatus dan bayi & $2-10$ & $100 \mathrm{ml} / \mathrm{kg}$ \\
Bayi dan anak & $10-20$ & $1000 \mathrm{ml}+50 \mathrm{ml} / \mathrm{kg}$ \\
& & diatas $10 \mathrm{~kg}$ \\
Anak & $>20$ & $1500 \mathrm{ml}+20 \mathrm{ml} / \mathrm{kg}$ \\
& & diatas $20 \mathrm{~kg}$ \\
\hline
\end{tabular}

Tabel 6. Jumlah kebutuhan cairan yang dianjurkan

Volume awal untuk pasien tanpa penyakit jantung atau ginjal.

$\begin{array}{rlrl}<10 \mathrm{~kg} & =100 \mathrm{ml} / \mathrm{kg} / \text { hari } \\ 10-30 \mathrm{~kg} & =200 \mathrm{ml} / \mathrm{m}^{2} / \text { hari } \\ 30-50 \mathrm{~kg} & =100 \mathrm{ml} / \text { jam } 2.400 \mathrm{ml} / \text { hari } \\ >50 \mathrm{~kg} & =124 \mathrm{ml} / \text { jam } ~ & \text { Æ } 3.000 \mathrm{ml} / \text { hari }\end{array}$

kebutuhan rumat tubuh juga diperlukan untuk pertumbuhan, karena protein pada anak lebih besar daripada orang dewasa. (Tabel 7)

Jumlah protein hendaknya sebesar 15\% dari kalori total serta rasio antara kalori nitrogen dan kalori nonnitrogen sebesar 1:150-200 untuk meningkatkan efisiensi penggunaan protein oleh tubuh. Beberapa asam amino (aa) selain aa esensial, dianggap esensial pada bayi terutama bayi BBLR, yaitu taurin dan sistein karena enzim sistationase pada hepar belum mencukupi untuk merubah metionin menjadi sistein dan taurin. Asam amino arginin penting dan diperlukan/esensial pada keadaan stres metabolik dan kadarnya lebih tinggi pada larutan aa. Pediatri, sebaliknya aa. Glutamin tidak ditambahkan pada larutan karena tubuh sudah mempunyai enzim glutamin sintetase yang dapat mensintesis glutamin dari glutamat

Tabel 7. Kebutuhan protein

\begin{tabular}{ll}
\hline Gol. Umur (tahun $)$ & Protein $(/ \mathrm{kg} /$ hari $)$ \\
\hline $0-1(+$ BBLR $)$ & $2.0-3.5$ \\
$1-7$ & $2.0-2.5$ \\
$7-12$ & 2.0 \\
$12-18$ & 1.5 \\
$>18$ & 1.0 \\
\hline
\end{tabular}


dan amonia. Asam amino rantai cabang (leusin, isoleusin dan valin) kadarnya lebih tinggi pada larutan aa yang diperuntukkan kasus hepatologi untuk mencegah dan mengobati ensefalopati hepatik.

Karbohidrat $(\mathrm{KH})$ : sebagai sumber energi di samping lemak, $\mathrm{KH}$ diberikan dalam jumlah 40-45\% dari kalori total. Berbagai bentuk $\mathrm{KH}$ yang umum digunakan adalah dekstrosa/glukosa, maltosa (glukosa polimer) dan xilitol dengan berbagai konsentrasi.

Lipid: merupakan nutrien dengan densitas kalori tinggi (9kkal/g) dan pada penggunaan untuk NP sebaiknya memasok 30-50\% energi non nitrogen. Selain sumber energi, lipid juga merupakan sumber asam lemak esensial (ALE, yaitu as. Linoleat dan as. Linolenat). Dilaporkan pada bayi yang mendapat NP tanpa larutan lipid, defisiensi ALE dapat terjadi dalam 2 hari. Untuk mencegah keadaan defisiensi ALE, as. Linoleat harus merupakan minimal $1 \%$ energi total dan umumnya 2$4 \%$ dari energi total berasal dari ALE.

Kebutuhan lipid untuk NP tertera pada Tabel 8. Emulsi lipid mengandung komponen purified soya bean, fosfolipid dan anhydrous glycerol. Emulsi lipid 10\% mengandung $1.1 \mathrm{kkal} / \mathrm{ml}$. Sedangkan emulsi lipid 20\% mengandung $2.0 \mathrm{kkal} / \mathrm{ml}$. Bila dimungkinkan sebaiknya pemberian intravena emulsi ini dilakukan selama 24 jam secara kontinyu dan sumber kalori yang berasal dari lipid tidak boleh melebihi $60 \%$ dari total kalori non protein. Penggunaan emulsi lipid 20\% lebih dianjurkan dibandingkan emulsi lipid 10\%.

Pemberian secara ekstra hati-hati harus dilakukan bila emulsi ini diberikan pada ${ }^{6}$

- Neonatus yang menderita hiperbilirubinemia.

- Neonatus yang sedang mendapat fototerapi

- Pasien yang mengalami gagal napas

- Pasien dengan sepsis berat

- Pasien dengan trombositopenia
Komplikasi akibat pemberian emulsi ini antara lain reaksi hipersensitivitas akut, bradikardi transien, TPN related cholestasis, risiko keolelitiasis meningkat, pankreratitis, gangguan pertukaran gas pernapasan, gangguan fungsi imun, trombositopenia, lepasnya ikatan bilirubin dari albumin.

Di bawah ini rekomendasi kebutuhan emulsi lipid perhari $^{8-10}$

Mineral dan elektrolit: pada NP diperlukan kalsium $(\mathrm{Ca})$, fosfor $(\mathrm{P})$, natrium $(\mathrm{Na})$, kalium $(\mathrm{K})$, klorida $(\mathrm{Cl})$, asetat dan magnesium $(\mathrm{Mg})$ dengan perhatian khusus pada kadar Ca dan P sehubungan dengan kemungkinan terjadinya presipitasi. Kebutuhan mineral dan elektrolit terdapat pada Tabel 9 dan Tabel 10 .

Beberapa trace elements telah merupakan bagian pada pemberian NP (Tabel 11), sedang pemberian zat besi $(\mathrm{Fe})$ masih kontroversial.

Vitamin : vitamin merupakan komponen nutrisi yang esensial dan berperan sebagai ko-ensim pada berbagai reaksi metabolik. Pada pemberian vitamin i.v sebagian akan hilang karena diabsorbsi atau menempel pada kantong/botol dan slang infus yang digunakan atau rusak karena terpajan cahaya, sehingga tidak mudah untuk menentukan dosis vitamin pada NP. Tabel 12 menunjukkan dosis vitamin yang dianjurkan pada pemberian secara i.v/ NP

\section{Pemilihan cairan dan cara pemberiannya $a^{5,6,8,9}$}

Umumnya cairan NP, baik larutan asam amino (aa), KH ataupun lipid digunakan larutan standar. Kadar larutan tergantung pada akses NP yang akan digunakan. Pada beberapa keadaan klinis seperti penyakit hati dan ginjal seringkali dibutuhkan larutan khusus terutama yang menyangkut susunan asam aminonya. Larutan aa untuk penyakit hepar mengandung kadar aa rantai cabang tinggi.

Tabel 8. Kebutuhan lipid untuk NP

\begin{tabular}{llll}
\hline Dosis & $\begin{array}{l}\text { Bayi prematur/ } \\
\text { KMK }\end{array}$ & Bayi aterm & Anak \\
\hline Inisial & $0.5-1$ & $1-2$ & 1 \\
& $5 \mathrm{ml} / \mathrm{kg} / \mathrm{h}$ & $10 \mathrm{ml} / \mathrm{kg} / \mathrm{h}$ & $10 \mathrm{ml} / \mathrm{kg} / \mathrm{h}$ \\
Peningkatan/ hari & $0.25-1$ & $0.5-1$ & $0.5-1$ \\
& $2.5 \mathrm{ml} / \mathrm{kg} / \mathrm{h}$ & $5 \mathrm{ml} / \mathrm{kg} / \mathrm{h}$ & $5 \mathrm{ml} / \mathrm{kg} / \mathrm{h}$ \\
Maksimum & $3-4$ & 4 & 2 \\
& $30 \mathrm{ml} / \mathrm{kg} / \mathrm{h}$ & $40 \mathrm{ml} / \mathrm{kg} / \mathrm{h}$ & $20 \mathrm{ml} / \mathrm{kg} / \mathrm{h}$ \\
\hline
\end{tabular}


Tabel 9. Mineral dan elektrolit untuk NP

\begin{tabular}{ll}
\hline Elektrolit/mineral & Jumlah/kg/hari \\
\hline $\mathrm{Na}(\mathrm{mEq})$ & $2.0-4.0$ \\
$\mathrm{~K}(\mathrm{mEq})$ & $2.0-3.0$ \\
$\mathrm{Cl}(\mathrm{mEq})$ & $2.0-3.0$ \\
Asetat $(\mathrm{mEq})$ & $1.0-4.0$ \\
$\mathrm{PO} 4(\mathrm{mM})$ & $0.2-2.0$ \\
$\mathrm{Ca}$ (glukonat) $\mathrm{mg}$ & $50-500$ \\
$\mathrm{Mg}$ (mEq) & $0.25-0.5$ \\
\hline
\end{tabular}

Tabel 11. Jumlah trace elements yang dianjurkan pada NP

\begin{tabular}{lllll}
\hline Elemen & $\begin{array}{l}\text { Prematur } \\
\mu \mathrm{g} / \mathrm{kg} / \mathrm{h}\end{array}$ & $\begin{array}{l}\text { Bayi } \\
\mu \mathrm{g} / \mathrm{kg} / \mathrm{h}\end{array}$ & $\begin{array}{l}\text { Anak } \\
\mu \mathrm{g} / \mathrm{kg} / \mathrm{h}\end{array}$ & $(\mathrm{maks} / \mathrm{h})$ \\
\hline $\mathrm{Zn}$ & 400 & $\leq 3 \mathrm{bln}: 250$ & 50 & 5000 \\
& & $>3 \mathrm{bln}: 100$ & & \\
$\mathrm{Co}$ & 20 & 20 & 20 & 300 \\
$\mathrm{Se}$ & 2.0 & 2.0 & 2 & 30 \\
$\mathrm{Mn}$ & 1.0 & 1.0 & 1 & 50 \\
Mo & 0.25 & 0.25 & 0.25 & 5 \\
$\mathrm{I}$ & 1.0 & 1.0 & 1 & 1 \\
$\mathrm{Cr}$ & 0.20 & 0.20 & 0.2 & 5 \\
\hline
\end{tabular}

Pemberian aa dimulai $0.5 \mathrm{~g} / \mathrm{kg} /$ hari pada neonatus $1 \mathrm{~g} / \mathrm{kg} /$ hari pada anak, selanjutnya dinaikkan sebanyak $0.5 \mathrm{~g} / \mathrm{kg} /$ hari sampai dosis maksimal tercapai. Pada keadaan adanya restriksi pemberian cairan, lebih disukai menggunakan preparat lipid dengan konsentrasi tinggi (20\%) agar tidak menambah jumlah cairan terlalu banyak tetapi dapat memenuhi kebutuhan kalori. Untuk memenuhi ALE dapat digunakan emulsi lipid yang mengandung minyak safflower. Emulsi lipid yang mengandung MCT (middle chain triglyceride) mempunyai nilai tambah karena MCT tidak ditimbun di hepar atau jaringan lemak serta mengalami proses hidrolisis dan oksidasi cepat yang juga tidak tergantung pada karnitin. Pemberian lemak dimulai dengan dosis rendah yang dinaikkan perlahan-lahan sampai dosis yang diperhitungkan tercapai. Pemberian dapat secara terusmenerus selama 24 jam atau hanya 18 jam dengan 6 jam 'istirahat' untuk memberikan kesempatan tubuh melakukan clearance.

\section{Akses pemberian $\mathrm{NP}^{5,6}$}

Pemberian NP dapat dilakukan melalui 2 cara yaitu akses vena sentral dan vena perifer. Pemilihan akses
Tabel 10. Jumlah Kalsium dan Fosfor yang dianjurkan

\begin{tabular}{lll}
\hline Gol.umur & $\begin{array}{l}\text { Ca glukonat } \\
(\mathrm{mg} / \mathrm{kg} / \mathrm{h})\end{array}$ & $\begin{array}{l}\text { Fosfat } \\
(\mathrm{mM} / \mathrm{kg} / \mathrm{h})\end{array}$ \\
\hline Prematur & $300-500$ & $1.0-1.5$ \\
Neonatus aterm & $300-400$ & $1.0-1.5$ \\
Bayi/anak & $100-200$ & 1.0 \\
Adolesen & $50-100$ & $0.5-1.0$ \\
\hline
\end{tabular}

Tabel 12. Dosis vitamin yang dianjurkan pada NP

\begin{tabular}{lll}
\hline Vitamin & $\begin{array}{l}\text { Prematur } \\
\text { (per hari) }\end{array}$ & Bayi/Anak (dosis/kgbb) \\
\hline A (IU) & 2300 & 1643 \\
D (IU) & 400 & 160 \\
E (IU) & 7 & 2.8 \\
K (mcg) & 200 & 80 \\
C (mg) & 80 & 25 \\
As.Folat (mcg) 140 & 56 & \\
Niasin (mg) & 17 & 6.8 \\
B 2 (mg) & 1.4 & 0.15 \\
B 1 (mg) & 1.2 & 0.35 \\
B 6 (mg) & 1.0 & 0.18 \\
B 12 (mcg) & 1.0 & 0.3 \\
As.Pantotenat (mg) & 5 & 2.0 \\
Biotin (mcg) & 20 & 6.0
\end{tabular}

apa yang dipakai didasarkan atas pertimbangan:

1. Lama dukungan nutrisi diberikan. Apabila dukungan nutrisi diberikan tidak lebih dari 14 hari maka dapat digunakan rute perifer, sebaliknya rute sentral digunakan bila NP direncanakan diberikan lebih dari 14 hari.

2. Konsentrasi larutan.

Pada akses vena sentral dimungkinkan untuk memberikan larutan dengan konsentrasi tinggi yaitu dekstrosa $25-30 \%$ yang merupakan larutan hipersomoler karena, memberikan osmolalitas sebesar 1200-1500 mOsm/L. Sedangkan dengan akses vena perifer konsentrasi dekstrosa yang ditoleransi hanya antara 5-10\% dengan osmolalitas sebesar 250-500 $\mathrm{mOsm} / \mathrm{L}$, walaupun beberapa penelitian menunjukkan bahwa konsentrasi dekstrosa sampai $12.5 \%$ masih dapat ditoleransi.

\section{Formula all in one/ three in one ${ }^{11}$}

Adalah pemberian NP yang mengandung dekstrosa, asam 
amino, emulsim lipid dalam 1 wadah. Keuntungan formula ini adalah lebih nyaman, pemberian infus lipid dapat lebih lambat, di samping lebih hemat karena penggunaan pompa dan pipa makanan menjadi berkurang. Lebih lanjut emulsi lipid yang isotonus menjadikan campuran larutan lebih rendah osmolalitasnya. Tetapi formula ini juga mempunyai kelemahan yaitu sulit memantau bila terjadi presipitasi pada larutan, di samping itu penelitian menunjukkan bahwa formula ini lebih berisiko untuk terjadinya pertumbuhan bakteri dibandingkan formula biasa.

\section{Osmolalitas}

Seperti telah disinggung pada pembahasan pemilihan rute NP, maka pada rute sentral dimungkinkan untuk memberikan larutan dengan osmolalitas lebih besar. Penelitian menunjukkan bahwa risiko terjadinya flebitis mulai akan tampak bila osmolalitas larutan melebihi 600 $\mathrm{mOsm} / \mathrm{L}$. Penelitian lain menunjukkan bahwa pada pasien yang mengalami gangguan aliran darah, endotel vena perifer hanya dapat mentoleransi osmolalitas sebesar $820 \mathrm{mOsm} / \mathrm{L}$ selama $8 \mathrm{jam}, 690 \mathrm{mOsm} / \mathrm{L}$ selama 12 jam dan $550 \mathrm{mOsm} / \mathrm{L}$ selama 24 jam. Dengan perkataan lain toleransi pembuluh darah terhadap osmolalitas menurun bila nutrisi enteral diberikan makin lama. ${ }^{12,13}$

Berikut ini besar osmolalitas beberapa larutan yang sering digunakan untuk NP5 . (Tabel 13)

\section{Cara menghitung/membuat NP5}

1. Hitung kebutuhan kalori, protein dan cairan

2. Lipid

Hitung kebutuhan lipid, umumnya 30\% dari jumlah kalori total

Kalori dari lipid = total kalori $\mathrm{x} 0.3$

Konversi kalori lipid ke dalam emulsi lipid (1.1 $\mathrm{kkal} / \mathrm{ml}$ untuk emulsi $10 \%, 2 \mathrm{kkal} / \mathrm{ml}$ untuk

Tabel 13. Besar osmolalitas beberapa larutan

\begin{tabular}{lllll}
\hline \multicolumn{2}{l}{ Komponen } & Kalori/L & $\mathrm{mOsm} / \mathrm{L}$ & Gram/L \\
\hline Dekstrosa & $10 \%$ & 340 & 504 & 100 \\
Dekstrosa & $20 \%$ & 680 & 1008 & 200 \\
As.Amino & $5.5 \%$ & 220 & 575 & 55 \\
As.Amino & $8.5 \%$ & 340 & 890 & 85 \\
Lipid & $10 \%$ & 1100 & 260 & 110 \\
Lipid & $20 \%$ & 2000 & 260 & 200 \\
Elektrolit & - & 235 & - \\
\hline
\end{tabular}

emulsi 20\%).

Emulsi lipid $(\mathrm{ml})=$ kalori lipid : 1.1 (2 untuk emulsi 20\%).

3. Protein

Hitung kebutuhan kalori, umumnya 15\% dari total kalori (untuk kebutuhan yang tinggi dapat mencapai 20-25\%).

Tentukan jumlah asam amino (protein) dengan membagi kalori yang berasal dari protein yaitu 4 $\mathrm{kkal} / \mathrm{g}$.

Kalori dari protein $=$ kalori total $\mathrm{x} 0.15$

Gram protein $=$ kalori protein $: 4$

Apabila digunakan larutan asam amino yang mempunyai konsentrasi 5\%, maka jumlah larutan asam amino yang dibutuhkan (ml) adalah:

Gram protein : 0.05

4. Dekstrosa

Hitung kebutuhan kalori yang berasal dari $\mathrm{KH}$.

Kalori dekstrosa $=$ kalori total - kalori lipid - kalori protein

Tentukan konsentrasi larutan dekstrosa yang akan digunakan (misalnya 40\%= $40 \mathrm{~g} / \mathrm{L}$ ). Sehingga jumlah larutan yang dibutuhkan = kalori dekstrosa: 0.04

5. Tambahkan aquades berdasarkan perhitungan kebutuhan cairan dikurangi dengan jumlah larutan lipid, protein dan $\mathrm{KH}$.

6. Sehingga komposisi akhir larutan NP adalah

............ ml dekstrosa $40 \%$
............ ml asam amino $5 \%$
.............. ml emulsi lipid 10\% (atau 20\%)
........... aquades

\section{Pemantauan $8,9,13$}

Harus dilakukan setiap hari terhadap keadaan klinis dan komplikasi yang mungkin terjadi, serta pemeriksaan laboratorium yang dimulai pada awal pemberian NP dan selanjutnya secara berkala tergantung keperluan/keadaan dan jenis pemeriksaan. (Tabel 14)

\section{Komplikasi NP}

Komplikasi NP dapat dikategorikan ke dalam 4 golongan:

1. Pemberian nutrisi tidak adekuat: - under/over nutrition 
Tabel 14. Pedoman pemantauan pemeriksaan laboratorium NP

\begin{tabular}{|c|c|c|c|c|}
\hline Laboratorium & Awal & Tiap hari & Tiap2-3 hari & Tiap minggu \\
\hline Elektrolit & $\sqrt{ }$ & & $\sqrt{ }$ & \\
\hline BUN, kreatinin & $\sqrt{ }$ & & $\sqrt{ }$ & \\
\hline Glukosa & $\sqrt{ }$ & $\begin{array}{c}\sqrt{ } \\
3 \mathrm{hr} \mathrm{I}\end{array}$ & $\sqrt{ }$ & \\
\hline$M g \& P$ & $\sqrt{ }$ & & & $\sqrt{ }$ \\
\hline $\mathrm{Ca}$ & $\sqrt{ }$ & & & $\sqrt{ }$ \\
\hline LFT & $\sqrt{ }$ & & & $\sqrt{ }$ \\
\hline Albumin \& prealbumin & $\sqrt{ }$ & & & $\sqrt{ }$ \\
\hline Kolesterol\& TG & $\sqrt{ }$ & $\begin{array}{c}\sqrt{ } \\
2 \mathrm{hr} I\end{array}$ & & \\
\hline Darah tepi & $\sqrt{ }$ & & $\sqrt{ }$ & \\
\hline $\mathrm{PT}$ & $\sqrt{ }$ & & & $\sqrt{ }$ \\
\hline Glukosa urin & $\sqrt{ }$ & $\begin{array}{c}\text { 4-6/hari } \\
3 \mathrm{hr} \mathrm{I}\end{array}$ & $\sqrt{ }$ & \\
\hline Nitrogen urea urin & & & & $\sqrt{ }$ \\
\hline
\end{tabular}

2. Metabolik: gangguan elektrolit, hypoglikemia, hiperglikemia, cholestatic jaundice, defisiensi vitamin, asam lemak, asidosis metabolik dan lainlain.

3. Mekanik: pnemotoraks, hemotoraks, emboli udara dan lain-lain.

4. Infeksi: sepsis, flebitis dan lain-lain.

\section{Penghentian NP}

Bila nutrisi enteral sudah dapat diberikan dan ditoleransi, maka NP secara bertahap dapat dikurangi seiring bertambahnya jumlah nutrisi enteral. Sebaiknya NP parenteral tidak dihentikan secara mendadak, tetapi dalam 24 jam, bahkan pada neonatus harus dilakukan dalam 2-3 hari. NP baru dihentikan seluruhnya bila asupan nutrisi enteral sudah mencapai $2 / 3$ kebutuhan. $^{6}$

\section{Daftar Pustaka}

1. Wilmore DW, Dudruck SJ. Growth and development of an infant receiving all nutrients exclusively by vein. JAMA 1968; 203:140, dikutip dari kepustakaan No.6.

2. Cuthberson D. Historical background to parentral nutrition. Acta Chir Scand 1980; 498(suppl):1-1i.

3. Elman R, Wiener DO. Intravenous alimentation with special reference to protein (amino acid) metabolism.
JAMA 1939; 112:796. Dikutip dari kepustakaan No.6.

4. Helfrick FW, Abelson NM. Intravenous feeding of a complete diet in a child. J Pediatr 1944; 25:400.

5. Dooling-Mc.Gurk EP, Ross VM, Pemberton BP. Total parenteral nutrition. Dalam: Van Way III CW, penyunting. Nutrition secrets. Philadelphia: Hanley \& Belfus, 1999. h. 179-223.

6. Bines J, Titchen T, Humphrey M, Jessen D. A practical guide to pediatric nutrition support. Royal children's hospital. Victoria, Australia, 1997.

7. Okada A. Clinical indication of parenteral and enteral nutrition support in pediatrics patients. Nutrition 1998; 14(1):116-8.

8. Teitelbaum DH, Coran AG. Total parenteral nutrition. Dalam: O’Neill JA, Rowe MI, Grosfeld JL, Fonkalsrud EW, Coran AG, penyunting. Pediatric surgery. St.Louis: Mosby, 1998. h. 183-96.

9. Noel RA, Udall Jr JN. Parenteral Nutrition. Dalam: Walker WA, Watkins JB, penyunting. Nutrition in pediatrics. London: BC Decker, 1997. h. 734-46.

10. Cox JH, Melbardis IM. Parenteral nutrition. Dalam: Samour PQ, Helm KK, Lang CE, penyunting. Handbook of pediatric nutrition. Maryland: Aspen Publication, 1999. h. 551-82.

11. Hardy G, Ball P, McElroy B. Basic principles for compounding all-in-one parenteral nutrition admixtures. Current opinion in clinical nutrition and metabolic care 1998; 1:291-6.

12. Kuwahara T, Asanami S, Kubo S. Experimental infusion phlebitis: tolerance osmolality of peripheral venous endothelial cells. Nutrition 1998; 14(6):496501 .

13. National advisory group on standards and practice guidelines for parenteral nutrition. Safe practices for parenteral nutrition formulations. J Parenteral \& Enteral Nutr 1998; 22(2):49-66. 